\title{
THE EFFECT OF RECOMBINANT VASCULAR ENDOTHELIAL GROWTH FACTOR 121 ON NITRIDE OXIDE LEVEL IN MICE (Mus musculus) MODEL OF PREECLAMPSIA
}

\author{
Soetrisno, Isharyadi, Sri Sulistyowati \\ Department of Obstetrics and Gynecology, Medical Faculty of Sebelas Maret University, \\ Dr Moewardi Hospital, Surakarta
}

\begin{abstract}
ABSTRAK
Preeklampsia adalah suatu sindrom multifaktorial pada kehamilan yang penyebabnya masih belum diketahui secara pasti. Beberapa mediator proangiogenik antara lain adalah Vascular Endothelial Growth Factor (VEGF) dan Nitrit Oksida (NO) mencegah terjadinya preeklamsia. VEGF diduga dapat meningkatkan kadar NO sehingga menurunkan tekanan darah maternal, perbaikan fungsi endotel dan mengurangi hipoksia plasenta pada preeklampsia. VEGF 121 rekombinan diharapkan menjadi pilihan dalam pencegahan dan terapi pada preeklampsia. Penelitian eksperimental digunakan hewan coba mencit (Mus musculus). Tujuan penelitian ini adalah untuk mengetahui efek VEGF 121 rekombinan dalam meningkatkan kadar nitrit oksida pada mencit model preeclampsia. Penelitian ini merupakan penelitian eksperimental rancang bangun Randomised Control Trail 27 hewan coba mencit bunting yang memenuhi kriteria ristriksi dibagi 3 kelompok. Kelompok (K1) 9 mencit bunting normal, kelompok (K2) 9 mencit bunting model preeklampsia tanpa perlakuan dan kelompok (K3) 9 mencit bunting model preeklampsia mendapatkan VEGF 121 rekombinan. Variabel bebas pemberian VEGF 121 rekombinan dan variabel tergantung kadar NO serum. Analisa statistik mengunakan uji anova. Kadar NO pada K1 sebesar 1,746 \pm 0.347 dengan nilai minimum 1,00 $\mu M$, maksimum 2,28 $\mu$ M dan CI

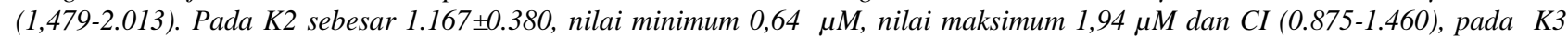
sebesar 2,164 \pm 0.556 dengan nilai minimum sebesar 1,56 $\mu M$, nilai maksimum sebesar 5,96 $\mu M$ dan CI (1,842-2.486). Dengan uji statistik anova didapatkan perbedaan yang bermakna pada K1 dengan K2 $(p=0.004<0.05)$, K1 dengan K3 $(p=0.000<0.05)$ dan K2 dengan K3 ( $p=0.029<0.05)$. Sebagai simpulan, VEGF 121 rekombinan secara bermakna meningkatkan kadar Nitrit Oksida pada mencit model preeklampsia. (FMI 2017;53:191-195)
\end{abstract}

Kata kunci: Vascular Endothelial Growth Factor 121 Rekombinan; nitrit oksida; mencit (Mus musculus); preeklampsia

\begin{abstract}
Preeclampsia is a multifactorial syndrome in pregnancy whose cause is still unknown. Several proangiogenic and antiangiogenic mediators such as Vascular Endothelial Growth Factor (VEGF) and Nitrite Oxide (NO) play important roles in preventing preeclampsia. VEGF can increase NO level that lowers maternal blood pressure, improves endothelial function and reduces placental hypoxia in preeclampsia. Recombinant VEGF 121 is expected to be an option in the prevention and treatment of preeclampsia. This experimental study used mice (Mus musculus) as the model. The objective of this study was to observe the effect of recombinant VEGF 121 in increasing the level of nitric oxide in mice (Mus musculus) model of preeclampsia. This was an experimental analytical study with Randomized Control Trial (RCT) design. The study enrolled 27 pregnant mice (Mus musculus) which met the restriction criteria divided into 3 groups. The first group (K1) were 9 normal pregnant mice. The second group (K2) were 9 pregnant mice of preeclampsia model without treatment. The third group (K3) were 9 pregnant mice of preeclampsia model receiving recombinant VEGF 121 therapy. The independent variable was the administration of recombinant VEGF 121 and the dependent variable was the serum NO level. Statistical analysis was performed by using anova statistics. NO level in the first group (K1) was 1.746 \pm 0.347 , with minimum value of $1.00 \mu M$, and maximum value of $2.28 \mu M, C I(1.479-2.013)$. NO level in second group (K2) was $1.167 \pm 0.380$, with minimum value of $0.64 \mu M$, and maximum value of $1.94 \mu M, C I(0.875-1.460)$. NO level in the third group (K3) was $2.164 \pm 0.556$, with minimum value of $1.56 \mu M$, and maximum value of $5.96 \mu M$, CI (1.842-2.486). With anova statistical test, there were significant differences between $K 1$ group and K2 group ( $p$ value $=0.004<0.05$ ), K1 group and K3 group ( $p$ value $=0.000<0.05)$ as well as K2 group and K3 group ( $p$ value $=0.029<0.05)$. In conclusion, Recombinant VEGF 121 increased the level of nitric oxide in mice (Mus musculus) model of preeclampsia significantly. (FMI 2017;53:191-195)
\end{abstract}

Keywords: Recombinant Vascular Endothelial Growth Factor 121; nitric oxide; mice (Mus musculus); preeclampsia

Correspondence: Soetrisno. Department of Obstetrics and Gynecology, Medical Faculty of Sebelas Maret University/Doctor Moewardi Hospital, Surakarta. Email: soetrisno-spogk@yahoo.com

\section{INTRODUCTION}

Preeclampsia is one of the specific forms of hypertension in pregnancy that involves multiple organs. Pree- clampsia generally occurs at the gestational age of 20 weeks and more. This disorder has a significant contribution to global maternal and perinatal morbidity as well as mortality. The incidence of preeclampsia ranges 
from $2-8 \%$ of all pregnancies. Furthermore, $10-15 \%$ of maternal deaths are associated with preeclampsia and eclampsia (Duley 2009).

The etiology and pathogenesis of preeclampsia have not yet been clearly defined. Many theories have evolved related to the etiology and pathogenesis of preeclampsia so that preeclampsia is also called 'the disease of theories' (Schlembach 2003). Spiral artery remodeling abnormalities are considered as the main cause of preeclampsia. This results in placental hypoxia, increased oxidative stress and maternal systemic inflammatory responses (Naljayan \& Karumanchi 2013).

Until now the molecular pathogenesis of preeclampsia is largely unknown, but recent evidence shows that there has been a change in the expression of placental anti-angiogenic factors responsible for the clinical manifestations of preeclampsia. The level of Soluble Fms-like tyrosine kinase 1 (sFlt-1) and soluble endoglin produced by the placenta increase in the maternal circulation a few weeks before the onset of preeclampsia. This protein binds to the receptor-binding domains of vascular endothelial growth factor (VEGF) and placental growth factor (PlGF). Increased sFlt-1 level in the maternal circulation will decrease the amount of free VEGF and PlGF level resulting in endothelial dysfunction with clinical manifestations of hypertension, proteinuria, and other systemic symptoms of preeclampsia (Steinberg et al 2011, Sibai 2016)

In preeclampsia, there is a decrease in NO level. As a consequence, there is vasospasm of blood vessels which will lead to placental hypoxia and inflammatory reactions resulting in increased oxidative stress. Oxidative stress causes an imbalance between antioxidant agents and reactive oxygen species formation of free radicals which ultimately will cause systemic endothelial dysfunction. This systemic endothelial dysfunction causes clinical manifestations such as hypertension, proteinuria and thrombocytopenia (Nakagawa 2007).

The relationship between VEGF and NO can be explained by the coupling of VEGF-NO pathway. Increased VEGF can enhance the production of endothelial Nitric Oxide Synthase (eNOS) and NO release from endothelial cells. The relationship between VEGF and NO that have been recognized, can be a new target in the prevention and treatment of preeclampsia. Currently, there is recombinant VEGF 121, called as exogenous VEGF (Shah 2007). Treatment by administration of recombinant VEGF 121 is expected to increase the level of NO which can decrease maternal blood pressure, improve endothelial function and reduce the hypoxic placenta in preeclampsia. Research using human samples could not be done due to ethical problems so that researchers used animal studies, mice (Mus musculus) as a sample. Mice were selected in this study because they have a good adaptability in the laboratory environment and are genetically similar to human (Comiskey et al 2013, Hladunewich \& Karumanchi 2007).

\section{MATERIALS AND METHODS}

This was an experimental analytical study with Randomized Control Trial (RCT) design. This study was performed in mice (Mus musculus) model who were adult females, with gestational age of fifteen days, to determine the difference in the level of nitric oxide (NO) among the serum of pregnant normal mice, pregnant mice model of preeclampsia without treatment of recombinant VEGF 121 and pregnant mice model of preeclampsia with recombinant VEGF 121 therapy.

The sampling process was performed on blood serum since various clinical manifestations of preeclampsia were often associated with decreased Nitric Oxide level in the maternal circulation. After obtaining the ethical approval from the research ethics committee of the Faculty of Veterinary Medicine, Universitas Airlangga, Surabaya, Indonesia, Number 648-KE, the research was begun with the process of fertilizing mice, by way of synchronization.

The following technic was used to fertilize the mice. Female mice aged 3 months, weighing 20-25 grams were injected with 5 IU Pregnant More Serum Gonadotropin (PMSG) hormone. 48 hours later were injected with 5 IU Human Chorionic Gonadotropin (hCG) hormone. The female mice were fertilized by mono mating system. Each one of female mice were inserted into a cage containing a male mice aged 7 months weighing \pm 60 grams. 17 hours after mating process, the diagnosis of pregnancy was made by the appearance of copulatory plug (a plug covering the mice vagina from the cervix to the vulva).

On the 1st day of pregnancy, samples were divided into three groups as follows: K1: consisting of 9 normal pregnant mice, $\mathrm{K} 2$ : consisting of 9 pregnant mice model of preeclampsia without treatment, and K3: consisting of 9 pregnant mice model of preeclampsia with recombinant VEGF 121 administration. During the 1st till the 4 th day of pregnancy, the $\mathrm{K} 2$ and $\mathrm{K} 3$ group, were given anti-Qa-2 treatment of 10 ngiv to induce preeclampsia. (Sulistyowati et al 2017). During the 11th until 14th day of gestational age, the K3 group was given a recombinant VEGF 121 injection of $125 \mathrm{mg} /$ kilograms body weight once daily. On the 15 th day, termination was performed in all three groups, then blood samples were 
collected from intra-cardiac in all groups of mice. From the existing samples, Elisa method was performed to determine the level of Nitrite Oxide in maternal plasma.

Data were analyzed using SPSS software (Software Package for Social Science). Kolmogorov-Smirnov statistical test was performed to see the significance of the data. If the data were significantly different, ANOVA statistical test was performed to compare the significance differences among the groups. The statistical calculation in this study used the significance level of 0.05 (confident interval of $95 \%$ ) so that the $p$ value of $<0.05$ can be interpreted as significant.

\section{RESULTS}

Recombinant VEGF 121 played a role in increasing the level of nitric oxide in mice (Mus musculus) model of preeclampsia significantly. Because of that, it is expected to be an option in prevention and therapy for preeclampsia.

The results of data analysis were obtained from 27 research samples meeting the inclusion and exclusion criteria divided into 3 groups. The first group (K1) were 9 normal pregnant mice. The second group (K2) were 9 pregnant mice of preeclampsia model without treatment. The third group (K3) were 9 pregnant mice of preeclampsia model receiving recombinant VEGF 121 therapy. Table 1 showed that NO level in the first group (K1) was $1.746 \pm 0.347$, with minimum value of 1.00 $\mu \mathrm{M}$, and maximum value of $2.28 \mu \mathrm{M}$, CI (1.479-2.013). NO level in second group (K2) was $1.167 \pm 0.380$, with minimum value of $0.64 \mu \mathrm{M}$, and maximum value of $1.94 \mu \mathrm{M}$, CI (0.875-1.460). NO level in the third group (K3) was 2.164 \pm 0.556 , with minimum value of 1.56 $\mu \mathrm{M}$, and maximum value of $5.96 \mu \mathrm{M}$, CI (1.842-2.486).

To find out the difference of nitric oxide serum level among those three groups, Post Hoc Test was performed by means of LSD. The full test results was presented in Table 2. Table 2 showed that there were significant difference between $\mathrm{K} 1$ and $\mathrm{K} 2$ group ( $\mathrm{p}$ value $=0.004$ $<0.05$ ), between $\mathrm{K} 1$ and $\mathrm{K} 3$ group ( $\mathrm{p}$ value $=0.000$
$<0.05$ ) as well as $\mathrm{K} 2$ and $\mathrm{K} 3$ group ( $\mathrm{p}$ value $=0.029$ $<0.05)$.

\section{DISCUSSION}

Nitric Oxide is a compound that maintains normal dilated blood vessel conditions for fetoplacental perfusion and maintains vascular tone. Pregnancy with risk factors such as maternal disease and oxidative stress is a disturbance of these angiogenic factors (Steinberg et al 2011). Decreased levels of Nitric Oxide (NO) in the maternal circulation have an important role in the occurrence of hypertension in pregnancy and can develop into preeclampsia. In several different studies the prognosis was poor in preeclampsia patients with low NO levels in maternal circulation (Markham \& Funai 2014).

Some previous studies found that the level of NO was lower in patients with severe preeclampsia: $3.04 \pm 0.43$ $\mathrm{ng} / \mathrm{mL}$, compared to normal pregnancy: $8.10 \pm 1.62$ $\mathrm{ng} / \mathrm{mL}(\mathrm{p}$ value $=0.00(>0.05)($ Damayanti et al 2015). In another study, the level of VEGF, PIGF and NO were lower in patient with severe preeclampsia, with $p$ value of $<0.005$ (Saha et al 2013). Research on human showed the lower level of VEGF in patient with preeclampsia at 8th-12th weeks of gestation $(14.24 \pm 8.73 \mathrm{ng} / \mathrm{ml})$ than in normal pregnancy $(96.88 \pm 144.29 \mathrm{ng} / \mathrm{ml})$ with $\mathrm{p}$ value $=0.044<0.05$ (Wiyono et al 2015). Another study showed VEGF level in patient with preeclampsia $(9.53$ $\pm 1.02 \mathrm{ng} / \mathrm{ml}$ ) and in normal pregnancy $17.41 \pm 8.05$ $\mathrm{ng} / \mathrm{ml}$ with $\mathrm{p}$ value $=0.00<0.05$ (Roswendi et al 2014). Low VEGF level was also associated with IUGR incidence. The average of VEGF level at IUGR was 9.4 $\pm 0.40 \mathrm{ng} / \mathrm{ml}$ and in normal pregnancy was $11.04 \pm 1.77$ $\mathrm{ng} / \mathrm{ml}$ with $\mathrm{p}$ value $=0.00<0.05$ (Nirwanasari et al 2014). Other results of the NO concentration were lower in preeclampsia but not statistically significant (Erdemoglu et al 2009). Several previous studies of recombinant VEGF 121 were proven to improve the placental histopathological feature, fetal weight growth disorder of mice, and elevated serum levels of PlGF in preeclampsia model of mice (Anggraini 2015, Prabowo 2015).

Table 1. The average value of nitric oxide level (unit in $\mu \mathrm{M}$ )

\begin{tabular}{|c|c|c|c|c|c|c|c|}
\hline \multirow{2}{*}{$\begin{array}{c}\text { Level of } \\
\text { Nitrite } \\
\text { Oxide }\end{array}$} & \multirow{2}{*}{$\mathrm{N}$} & \multirow{2}{*}{ Average } & \multirow{2}{*}{$\begin{array}{l}\text { Standard } \\
\text { deviation }\end{array}$} & \multicolumn{2}{|c|}{$\begin{array}{l}95 \% \text { confidence } \\
\text { interval }\end{array}$} & \multirow{2}{*}{ Min } & \multirow{2}{*}{$\operatorname{Max}$} \\
\hline & & & & $\begin{array}{c}\text { Lower } \\
\text { limit }\end{array}$ & $\begin{array}{l}\text { Upper } \\
\text { limit }\end{array}$ & & \\
\hline K1 & 9 & 1.746 & 0.347 & 1.479 & 2.013 & 1.00 & 2.28 \\
\hline $\mathrm{K} 2$ & 9 & 1.167 & 0.380 & 0.875 & 1.460 & 0.64 & 1.94 \\
\hline K3 & 9 & 2.164 & 0.419 & 1.842 & 2.486 & 1.56 & 2.96 \\
\hline Total & 27 & 1.692 & 0.556 & 1.472 & 1.912 & 0.64 & 2.96 \\
\hline
\end{tabular}


Table 2. The result of post hoc test (LSD)

\begin{tabular}{|c|c|c|c|c|c|c|}
\hline \multirow[t]{2}{*}{ No } & \multirow{2}{*}{$\begin{array}{c}\text { Groups } \\
\text { compared }\end{array}$} & \multicolumn{3}{|c|}{ Average value ( $\mathrm{M})$} & \multirow{2}{*}{$\begin{array}{l}\text { Significance } \\
\text { (sig.) }\end{array}$} & \multirow[t]{2}{*}{ Conclusion } \\
\hline & & K1 & $\mathrm{K} 2$ & K3 & & \\
\hline 1 & $\mathrm{~K} 1-\mathrm{K} 2$ & 1.7456 & 1.1672 & & 0.004 & Significantly different \\
\hline 2 & $\mathrm{~K} 1-\mathrm{K} 3$ & 1.7456 & & 2.1641 & 0.000 & Significantly different \\
\hline 3 & $\mathrm{~K} 2-\mathrm{K} 3$ & & 1.1672 & 2.1641 & 0.029 & Significantly different \\
\hline
\end{tabular}

In animal studies using mice according to Woods et al, VEGF 121 prevented hypertension and proteinuria that could reduce the symptoms of preeclampsia. Treatment with the administration of recombinant VEGF $121 \mathrm{had}$ the ability to inhibit blood circulation of sFlt-1, decrease maternal blood pressure, improve endothelial function and reduce placental hypoxia (Prabowo 2015). Recombinant VEGF 121 could be considered as a therapy in preeclampsia (Woods et al 2011, Li et al 2007). In mice studies of preeclampsia model, it was found that recombinant VEGF 121 could improve glomerular endotheliosis. The average of glomerular endothelium in normal pregnant mice was 1.60 and pregnant mice model of preeclampsia was 1.90 with $p$ value $=0.28$ $(\mathrm{p}>0.05)$. The average value of glomerular endotheliosis in mice model of preeclampsia was 1.90 and mice model of preeclampsia model with recombinant VEGF 121 therapy was 1.30 with $p$ value $=0.02(p<0,05)$. The average value of glomerular endotheliosis in normal pregnant mice was 1.60 and mice model of preeclampsia with recombinant VEGF 121 therapy was 1.30 with $\mathrm{p}$ value $=0.28$ ( $\mathrm{p}>0.05)$ (Irawan et al 2016). Another study showed that recombinant VEGF 121 was proven to improve placental endothelial dysfunction of preeclampsia model mice, as evidenced by a lower average decrease in VCAM-1 expression (2.14) compared to the average value of mice without recombinant VEGF 121 therapy $(2.94)$ (p value $=0.035<0.05)$ (Sondakh et al 2016).

\section{CONCLUSION}

Recombinant VEGF 121 played a role in increasing the level of nitric oxide in mice (Mus musculus) model of preeclampsia significantly

\section{REFERENCES}

Anggraini ND (2015). The effect of recombinant VEGF 121 on histopathological image changes of placenta and fetal weight in mice (Mus musculus) model of preeclampsia

Comiskey M, Warner CM, Schust DJ (2013). MHC molecules of the preimplantation embryo and trophoblast. Available from http://www.ncbi.nlm.nih.
gov/books/NBK6277/. Published 2013. Accessed September 21, 2016

Damayanti PD, Sulistyowati S, Respati SH (2015). Differences of endothelin-1 serum (ET-1) and nitrit oxide (NO) among preeclmapsia late onset and and normal pregnancy. Obstetrics and Gynecology of Medical Faculty UNS/DR Moewardi Hospital Surakarta

Duley L (2009). the global impact of pre-eclampsia and eclampsia. Semin Perinatol 33, 130-137. doi: 10.1053 /j.semperi.2009.02.010.

Erdemoglu E, Ugur M and Erdemoglu E (2009). Plasma homocysteine and nitric oxide level in preeclampsia. Dep Obstet Gynecol Zekai Tahir Burak Women Heal Res Educ Hosp Ankara, Turkey A Turkish-German Gynecol Assoc; 10 26-9

Hladunewich, Karumanchi L (2007). Pathophysiology of the clinical manifestations of preeclampsia. Clin $\mathbf{J}$ Am Soc Nephrol 2, 543-549. doi: 10.2215 / CJN.03761106.

Irawan D, Sulistyowati S, Edwin E, Obstetrics D (2016). Recombinant VEGF 121 can improve glomerular endothelosis in pregnant mice model of Preeclampsia. Maj Ginekol Obstet, 24

Li Z, Zhang Y, Ma JY, et al (2007). Recombinant vascular endothelial growth factor 121 attenuates hypertension and improves kidney damage in a rat model of preeclampsia. Hypertension 50, 686-92

Markham KB, Funai EF (2014). Pregnancy-related hypertension classification of hypertensive disorders. In: Robert K. Creasy, Robert Resnik, Michael F. Greene, Jay D. Iams CJL, Thomas R. Moore, eds. Creasy and Resnik's Maternal-fetal medicine: principles and practice, China, Elsevier Saunders, $p$ 756-781

Nakagawa $T$ (2007). Uncoupling of the VEGFendothelial nitric oxide axis in diabetic nephropathy: an explanation for the paradoxical effects of VEGF in renal disease. Am J Physiol 292, F1665-F1672. doi: 10.1152/ajprenal.00495.2006

Naljayan MV, Karumanchi SA (2013). New developments in the pathogenesis of preeclampsia. Adv Chronic Kidney Dis 20, 265-270

Nirwanasari R, Sulistyowati S, Respati SH (2014). Intra uterine growth restriction: the role of vascular endothelial growth factor (VEGF) and soluble fms- 
like tyrosine kinase-1 (sFlt-1) in its Pathogenesis, Surakarta, Universitas Sebelas Maret

Prabowo W (2015). Effect of recombinant VEGF 121 on placenta growth factor (PlGF) in mice (Mus musculus) model of preeclampsia

Roswendi A, Sulistyowati S, Respati SH, Kartika H (2014). Level of soluble human leukocyte antigen-G (sHLA-G), vascular endothelial growth factor (VEGF) and soluble fms-like tyrosin kinase-1 (sFlt-1) in preeclampsia . Maj Ginekol Obstet 22

Saha T, Halder M, Das A, Das SK (2013). Role of nitric oxide, angiogenic growth factors and biochemical analysis in preeclampsia 50 462-466

Schlembach D (2003). Preeclampsia - still a disease of theories. Fukushima J Med Sci 49, 69-115.

Shah DM (2007). Preeclampsia: new insights. Curr Opin Nephrol Hypertens 16, 213-220

Sibai BM. Preeclampsia and hypertensive disorders of pregnancy. In: Steven G. Gabbe, Jennifer R. Niebyl, Joe Leigh Simpson MD, Mark B. Landon MD, Henry L. Galan MD, Eric RM Jauniaux MD, PhD, Deborah A. Driscoll MD, Vincenzo Berghella MD and William A. Grobman MD M, ed. Elsevier Inc. Seventh Ed.
Philadelphia: Elsevier Inc. 661-705. doi: 10.1016 / B978-0-323-32108-2.00031-7

Sondakh JA, Sulistyowati S, Respati SH (2016). Recombinant vascular endothelial growth factor 121 decreases vascular cell adhesion molecule-1 in murine pre-eclampsia placenta model. Universa Med 35

Steinberg G, Khankin E V., Karumanchi SA (2011). Angiogenic factors and preeclampsia. Semin Nephrol 31, 33-46. doi: 10.1016 / S0049-3848 (09) 70020-9.

Sulistyowati S, Bachnas MA, Anggraini ND, et al (2017). Recombinant vascular endothelial growth factor 121 injection for the prevention of fetal growth restriction in a preeclampsia mouse model. J Perinat Med 45, 245-51. doi: 10.1515/jpm-2016-0149

Wiyono BE, Sulistyowati S, Respati SH (2015). Angiogenic Factors Soluble FMS-Like Tyrosine Kinase-1 and Vascular Endothelial Growth Factor in Pregnant Women of 8-20 Gestational Weeks with Risk of Preeclampsia. J Kesehatan Reproduksi 2

Woods AK, Hoffmann, Weydert, Butler, Zhou, Sharma (2011). Adenoviral delivery of VEGF 121 early in pregnancy prevents spontaneous development of preeclampsia in BPH / 5 Mice. Hypertension.2011 Jan; 57 (1): 94-102. Hypertension 57, 94-102 